\title{
COGNITIVE-BEHAVIORAL APPROACH IN PHYSICAL HEALTH COMPETENCE DEVELOPMENT
}

\section{IRYNA SNYADANKO ${ }^{1}$, MARIANNA TKALYCH ${ }^{2}$, OKSANA VOITSEKHOVSKA ${ }^{3}$}

\author{
${ }^{1}$ Doctor of Psychological Sciences, Department of Theoretical and Applied Psychology at Lviv \\ Polytechnic National University, Lviv (Ukraine) \\ ORCID ID: https://orcid.org/0000-0003-4245-1443 \\ ${ }^{2}$ Doctor of Psychological Sciences, Psychology Department at Ukrainian State Employment \\ Service Training Institute, Kyiv (Ukraine) \\ ORCID ID: https://orcid.org/0000-0003-4101-9659 \\ ${ }^{3} \mathrm{PhD}$ in Psychology, Department of Theoretical and Applied Psychology at Lviv Polytechnic \\ National University, Lviv (Ukraine) \\ ORCID ID: https://orcid.org/0000-0003-4101-9659
}

UDC: 159.9

\begin{abstract}
SUMMARY
The article is devoted to the research of cognitive-behavioral approach implementation specifics in psychological consulting aimed at physical health competence development. The purpose was revealed as well as the main notions of social-cognitive approach that was elaborated by A. Bandura and further on developed by the representatives of his school. In particular, the main notions were reviewed such as: self-efficiency, acquired self-helplessness, control scale, competence. According to A. Bandura the notion of self-efficacy means individual confidence in themselves and ability to execute certain activity. Meanwhile acquiring selfefficacy can be done the following ways: ability to develop behavior, experience, verbal opinions, and emotional state. The comparative analysis of the notions 'competence' and 'competency' was done. The conclusion was drawn that the notion of 'competence' means individual ability to efficiently perform some activity, such as confidence in oneself and one's capabilities to do some activity, but the notion of 'competency' means the level of the capability implementation. The cognitive-behavioral approach (A. Beck, A. Ellis) was validated, the working model for psychological problem with the help of cognitive be-
\end{abstract}

Address for correspondence, e-mail: editpsychas@gmail.com

Copyright: (C) Iryna Snyadanko, Tkalych Marianna, Oksana Voitsekhovska

This is an Open Access journal, all articles are distributed under the terms of the Creative Commons AttributionNonCommercial-ShareAlike 4.0 International (CC BY-NC-SA 4.0) License (http://creativecommons.org/licenses/by-nc$\mathrm{sa} / 4.0 /$ ), allowing third parties to copy and redistribute the material in any medium or format and to remix, transform, and build upon the material, provided the original work is properly cited and states its license. 


\begin{abstract}
havioral scheme. Within the cognitive behavioral approach the essence of the competency amounts to the set of the following components: cognitive, emotional, and behavioral. The analysis of the notions 'physical health' and 'physical health competence' was done. It was shown the experimental research results aimed at individual physical heath competence development. The research result comparison of the development level of physical health competence before the beginning and after the end of experimental research tell us about the increase in amount of people under study with the high level of self-efficacy in actions focused on physical health self-improvement. The conclusion was made that cognitive behavioral approach implementation is effective for physical health competence development.
\end{abstract}

Keywords: self-efficacy; competence; cognitive behavioral approach; physical health.

\section{Introduction}

Physical health describes the current state of human body organs and systems, their development level and functional capabilities, and adaptation level to different environmental factors. (Murza, 1991). A good physical health is characterized by the number of main physiological systems within physiological normal range and they are changing adequately to the person's interaction with the environment. (Chepyga \& Chepyga, 2006). The care of physical health of the person should start from the pre-embryo period and continue throughout the whole life (Murza, 1991). The main principles of physical health formation are: providing the optimal living conditions (absence of stresses, adequate nutrition, and sufficient sleep); timely utilization of training actions; and disease prevention. Physical activity is an excellent way to maintain good physical and mental health. It's worth mentioning that the modern generation has lowered interest to physical activity and sport that negatively impacts the overall population health (Melnyk, 2019).
One of the crucial objective of psychological consulting is not only developing positive attitude towards maintaining and improving each own physical health but also, and first of all, developing an appropriate competence which will encourage not only raising the awareness of the necessity for physical health preservation but also implementation of the behavioral pattern towards improving physical health in a person's life. Thus, the article objectives are: 1) carrying out the analysis of social cognitive and cognitive behavioral approaches in psychology and psychological counseling as such that improve developing of competences of an individual; 2) study the influence of physical health competence on individual development of physical health.

One of the modern and efficient approaches in psychologist's work is cognitive behavioral approach. The development of cognitive behavioral approach starts with social cognitive approach by A. Bandura (Bandura, 1992), who introduced the notion of 'self-efficacy'. By 'selfefficacy' he meant a person's belief in his/her 
own abilities and ability to do certain activity. The more self-belief the person has in his/her abilities to do a particular activity or perform a particular behavior by A. Bandura, the higher self -efficacy level this person has in the particular activity, and the less the person believes in his/ her-self and his/her abilities to perform the particular activity or behavior, the lower his/her selfefficacy level is within this activity.

The negative outcome of the situation is based on the opposite tendency: thoughts about lack of success, possible failure, disbelief in own abilities cause 'helplessness' (psychological state that is the result of uncontrollable and unpleasant events and manifest itself in disorders of person's emotional, motivational, and cognitive processes) (Abramson, Seligman \& Teasdale, 1978). Helplessness, or as it is also named 'learned helplessness' (Ziering, 2006), is opposite to 'selfefficacy'. The example of learned acquired helplessness is the situations when a person, after a couple of unsuccessful attempts to do or achieve something, gets disappointed in oneself and one's abilities.

J. Rotter's research (Rotter, 1978) states that a high externality level of an individual can be the result of disappointment in oneself and lack of positive outcome in personal achievements. D. Ziering's research (Ziering, 2006) also indicates that learned helplessness negatively influences students' performance and their professional growth.

A. Bandura (Bandura, 1986) also empha- sizes the importance of independent influences as causative factor in all aspects of human functioning: motivations, emotions, and actions. The most evident statement in his self-efficacy concept is that a person can learn to control events that impact his/her own life. Social cognitive theory by A. Bandura explicitly explains the human behavior through the correlation among behavior, learning sphere, and environment. By the definition of 'mutual determination', A. Bandura understood that directivity factors and situational factors are interrelated causes of human behavior such as faith and expectations, and external determiners such as encouragement and punishment are part of the system of interrelated influences which impact not only the behavior but also different parts of social system.

A. Bandura (Bandura, 1986) introduced a postulation about cognitive technique of selfefficacy to explain individual functioning and changes. He assumed that acquiring self-efficacy can be done the following ways: ability to create the behavior, experience, verbal statements, and emotional state.

Social behavioral approach by A. Bandura had an influence on the development of cognitive behavioral approach to understand and solve psychological and psychosomatic problems of a person. The founders of cognitive behavioral approach are A. Beck (Beck, 1976) and A. Ellis (Ellis, 2008), who included emotional reactions in the basis of psychological problems; emotional reactions appear as a result reality distortion on 
the ground of mistaken assumptions, generalizations, etc. A. Ellis tended to look for semantic characteristics of cognitive processes in all emotional disorders, meanwhile A. Beck tried to differentiate different emotional state on the ground of cognitive matter.

In A. Beck's opinion, the important aspect in self-esteem and own abilities within certain activity are cognitions (lat. cognitio - knowledge, learning), thoughts about oneself that impact emotions, which in turn, impact person's behavior in certain situations. Those three componentscognitions, emotions, and behavior - are interconnected among themselves. (Figure 1).
That's why cognitive behavioral approach and its working techniques are very popular in clinical psychology, especially in therapy of depression, phobias, and obsessive thoughts.

Negative cognitive self-beliefs create negative emotional feelings, for example, anxiety, discomfort, etc. To reduce anxiety level, a person can unconsciously choose non-effective ways of self-regulation, such as: distraction to lower intensity of pain and emotional feelings, contemplation (focusing on symptoms of depressing mood), about reasons and consequences of those symptoms, that lead to many disorders, in particular, to depression, worry - constant focusing on

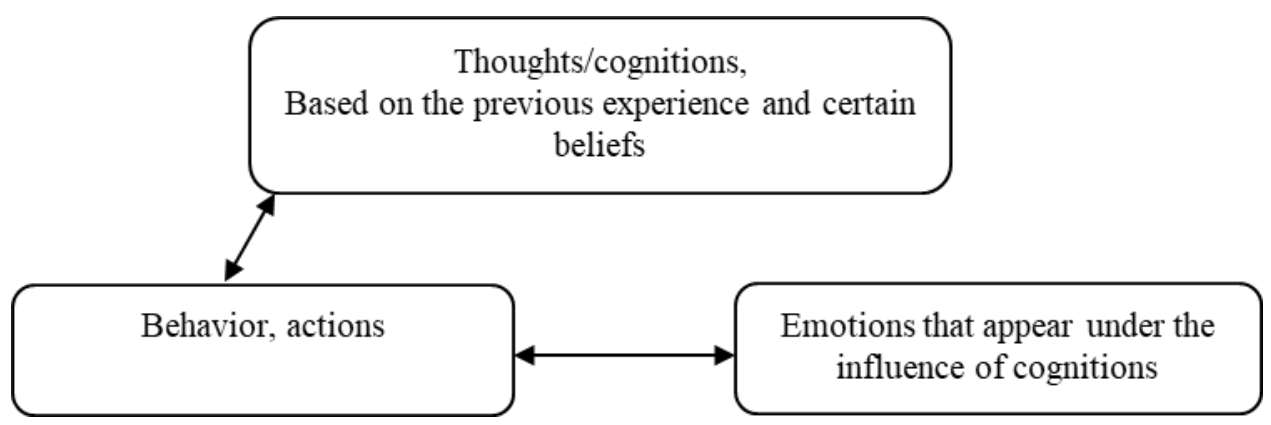

Fig. 1. Cognitive behavioral model of human behavior

The previous experience has a significant influence on the thought formation about oneself, one's abilities, and ability to act in certain situations. As A. Bandura states (Bandura, 1986) that the previous experience impacts our behavior or the algorithm of actions we choose, and that experience expresses itself as an reinforcement of one, the most desirable or approved by others behavioral model, or such a behavior that allows to get out of the situation with minimal losses. negative thoughts, images, that project negative picture of the future.

High self-efficacy level in personality is achieved with the formation of such cognitive beliefs, person's thoughts about themselves and their abilities so that it will facilitate in increasing self-belief, belief in one's abilities to attain set goals. But low self-efficacy level, vice versa, is characterized by presence of negative cognitive beliefs, low self-esteem level regarding one's 
abilities to perform certain activity, or to attain the results.

Interrelation of person's cognitions, emotions, and behavior in certain situations or field of activity creates certain psychological new formation (Zimnyaya, 2004), which is called competence. As F. Delamare and J. Winterton claim (Delamare \& Winterton, 2005) the notion of 'competence' should not be equated with the notion of 'competency'. The notion of 'competence' (English 'competence' - skill, ability act within given authority, ability to act according to the appropriate skills) is described by foreign and Ukrainian scientists as ability to perform certain functions, which are a part of certain professional authorities. The notion of 'competency' (English «competency» - a right to act) is described as the one which is more on the behavioral level as an individual characteristic, the person's ability to perform an activity effectively, as a self-confidence, confidence in own abilities to perform the activity.

Thus, competence means person's ability to perform activity effectively, as self-confidence, confidence in own abilities to perform the activity, meanwhile competency is a level of implementation of those abilities. (Snyadanko, 2016).

First of all, it's worth emphasizing that learner centered approach (Zimnyaya, 2004), which consider the competence as a certain inner potential psychological new formations (knowledge, perceptions, program of actions, system of values and attitudes), that later show up in the competence of a person as actual and activitybased manifestations.

The level of self-confidence, confidence in own actions and abilities to perform certain activity is called self-efficacy level by A. Bandura, this level is also a person's subjective assessment of his/her own abilities to act in a certain situation. As the researcher puts it, the formation of the 'subjective assessment' is influenced by the previous experience and the assessment of others. A person action algorithm which A. Bandura named as competent, by utilizing of which led to the success within certain activities, meanwhile an array of actions, person's perceptions about oneself, one's abilities to perform the activity was called competence.

Person's competences are also explained as individual characteristics of a personality (motives, traits, I-concept, attitudes and values, cognitive or behavioral skills), which can be measured to identify the differences between effective and ineffective action-doers. (Spencer L. M., McClelland, D. C. \& Kelner, S. 1998).

Within cognitive behavioral approach, the competence content is an aggregate of the following components: cognitive, emotional, and behavioral (Figure 2). Cognitive component comprises cognitions (Lat. cognition - to think. The definition of 'cognition' was introduced by the representatives of cognitive behavioral approach (Beck, 1976). The notion of 'cognition' should be recognized as beliefs and interpretation of oneself or situation that person found themselves in, 
meaning that they attach to the events in their lives, as well as self-understanding and one's role in these events. In other words, the cognitive component includes person's knowledge about themselves, their abilities to perform certain activity, ability for self-assessment, and assessment of one's abilities. Cognitions are being created according to the previous person's experience which can vary from positive to negative.

Emotional component lies in the fact that cognitions influence person's emotions triggering certain emotional reaction in response. Positive cognitions, previous positive experience trigger positive emotions, but negative cognitions cause negative emotions and feelings. Negative emotions which develop under the influence of cognitions are the reason for emotional self-regulation disturbance, especially in teenagers and youngsters. (Gross \& Thompson, 2007). The correction of an emotional self-regulation mechanism is one of the most important tasks in order to develop physical health competence.

Behavioral component involves performing certain actions, algorithm of behavior, which in turn, depends on personality's emotions and cognitions. Negative emotions, which appeared due to the cognitions, determine inefficient behavior, meaning the behavior which doesn't lead to the result that the person wanted to get. The person's behavior, actions which do not lead to anticipated result, A. Bandura named as behavior with a low level of self-efficacy. Positive emotions appearing due to positive cognitions contribute to choosing efficient behavioral strategies, or according to A. Bandura, such a behavior is going to be called as self-efficient.

The correlation between competence components is going to be characterized. It's worth mentioning that all competence components are interrelated. Qualitative changes in one component cause changes in other ones. As mentioned above, cognitions mean student's thoughts about oneself, one's abilities regarding performing certain activity provoke certain emotional reaction. If a person at the cognitive level does not believe in his/her abilities in a certain activity, then, at the emotional level, he/she can feel fear, anxiety or panic, etc. On conditions that when a student

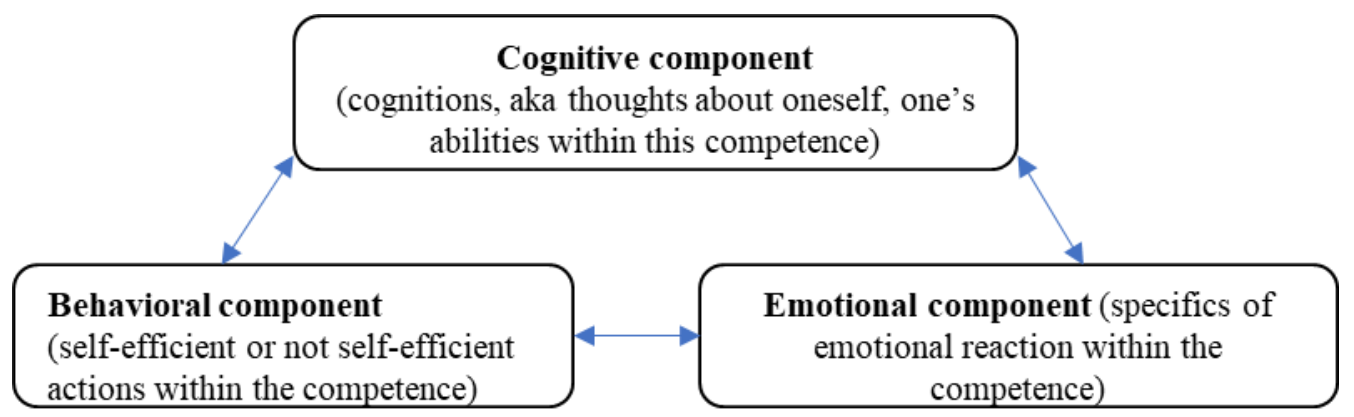

Fig. 2 Competence structure 
thinks (at the cognitive level) that he/she can perform the activity because he/she had a positive previous experience, then at the emotional level, he/she will experience positive emotions, for example: confidence, power, moderate excitement, etc. Emotional reaction, in its turn, determines human behavior specific traits which can be selfefficient or inefficient.

Person's actions and behavior impact the person's cognitions as well. Not self-efficient behavior influences a cognitive component. At the cognitive component level either confirmation of person's negative cognition or formation of new negative cognitions take place. Person's selfefficient behavior in a certain situation impacts cognitive component the way that confirms present positive cognitions or forms new positive cognitions.

\section{Material and Methods}

Participants. 50 students took part in the research, 26 of them comprised an experimental group; meanwhile 24 people were in control group. The participants from the experimental and control groups were equally distributed according to the gender and age. The participants' age ranged from 18 to 21 years old, $59 \%$ of them were female and $41 \%$ male in each group.

\section{Organization of the Research.}

The physical health competence formation was accomplished with the help of a specially elaborated psychological training program. First stage of the training aimed at acquiring knowledge on physical health aspects. At the beginning of the experimental research the control and experimental group participants were asked to listen to the lecture about human physical health. The lecture covered basic principles and factors that impact physical health formation, as well as conditions and methods which assist in improving physical health throughout the whole life. After the lecture, the control and experimental group participants were asked to determine their own motivation level regarding their own physical health improvement. The research participants also had to describe goals that they are trying to attain in developing and improving their physical health.

At the next stage of the experimental research the participants of control group were asked to reach their set goals in maintaining healthy life style and improving their physical health within three month period. The experimental group participants were asked to proceed to the second stage of the psychological training that was focused on physical health competence formation. At the second stage of the training only experimental group participants took part in it.

At this experimental research stage (psycho-correctional stage) the participants had an opportunity under trainer's supervision to do analysis of their own cognitive beliefs and barriers, which contribute or prevent physical health preservation and maintenance. At the second stage of the experimental research the psychological work was carried out with the help of using 
the methods and techniques developed within the cognitive behavioral approach, analysis of which is mentioned above.

The participants were asked to think about the goal that they desire to reach regarding improving their own physical health, and then to write down their own cognitive beliefs, thoughts, emotions, worry, that they experienced while contemplating about it. The received results are discussed with the trainer, who distinguished dominating cognitions, which can hinder the selfefficacy behavior formation within the physical health competence.

At the next stage, the participants together with the trainer write down the current cognitive behavioral model which they use regarding their own physical health (Figure 1). The current participants' cognitive behavioral model was developed under the influence of previous life experience and activity which in return, influenced the formation of current cognitive beliefs about oneself and one's abilities to reach set goals regarding one's own physical health. Each participant of the research wrote down behavioral models according to the scheme shown in Figure 1.

At the next stage the cognitive behavioral model analysis was conducted. The participants had to remember and analyze their previous experience of successes and failures which facilitated or hindered the formation of positive experience of physical health improvement and maintenance.

After the analysis of their own selfefficacy or helplessness in physical health devel- opment and maintenance, the participants of the experimental group had to develop a new selfefficient model. Self-efficient behavioral model in physical health development and maintenance were also designed according to the scheme presented in Figure 2.

At the next stage the experimental group participants had to do first steps within 2 to 3 months to reach their goals based on the new cognitive behavioral model. While implementing the objective the experimental group participants had to meet once a month to discuss the attained personal results regarding their own physical health, they also had an opportunity to correct their own model under the supervision of the trainer, and to measure their self-belief in their abilities to reach the desired result.

Upon the completion of the experimental research the survey in the control and experimental groups was conducted regarding the development level of physical health competence.

\section{Statistical Analysis.}

The analysis of physical health competence development was done with the help of comparing the results attained by the control and experimental group participants after the lecture and the completion of the experimental research.

Upon the lecture attended at the beginning of the experimental research the control and experimental group participants were asked to evaluate on the scale from 0 to $100 \%$ the following statements: 1) "How much are you planning to 
improve your own physical health?" 2) "How close are you to your set goal regarding improving and maintaining your own physical health?". In addition, the participants were asked what real steps they have already done to reach their goals, and define which personal characteristics, in their opinion, are necessary to reach the results regarding their own physical health, and how well those traits are expressed in their own personalities (from 0 to $100 \%$ ).

The received results before the experiment were divided onto three equal competence development levels, such as: a low level was seen in $34.62 \%$ of the experimental group participants, medium - $38.46 \%$, and high- $26.92 \%$; the control group observed $29.17 \%$ - low level, medium $-41.67 \%$, and high -29.16 of participants (Table 1).

Upon the completion of the experimental research the control and experimental groups participants were asked to assess the following statements according to the scale from 0 to $100 \%$ : 1)
"How much do you believe in your abilities to reach your goals to improve and maintain physical health right now?", 2) "How close are you to your goal right now?". The participants also wrote down the exact steps they did to reach their goals, as well as compared a level of their won characteristics development that facilitate in reaching their goals to improve and maintain their physical health.

Upon the experimental research completion the following results were attained: in the experimental group $11.54 \%$ participants had a low level, $38.46 \%$ - medium level, $50.00 \%$ participants had a high level; in the control group $29.17 \%$ of participants had a low level, $45.83 \%$ had a medium level, and $25.00 \%$ of participants had a high level (Table 1).

Statistical data processing was done with the help of statistical program SPSS («Statistical Package for the Social Science») version 19.00. According to the comparative analysis results (due to Wilcockson's criterion, $\mathrm{p} \leq 0,01$ ) statisti-

Table 1. The dynamics of physical health competence development in the participants before the beginning and after the completion of forming experiment in the experimental and control groups

\begin{tabular}{|l|c|c|c|c|}
\hline $\begin{array}{l}\text { Development } \\
\text { levels }\end{array}$ & $\begin{array}{c}\text { Levels of physical health competence } \\
\text { development (results are shown in \% ) } \\
\text { Experimental group }\end{array}$ & $\begin{array}{r}\text { Levels of physical health competence de- } \\
\text { velopment }\end{array}$ & $\begin{array}{r}\text { (results are shown in \% ) } \\
\text { Control group }\end{array}$ \\
\hline & $\begin{array}{c}\text { Data slice 1 } \\
\text { (before experi- } \\
\text { ment started) }\end{array}$ & $\begin{array}{c}\text { Data slice 2 } \\
\text { (after experiment } \\
\text { completion) }\end{array}$ & $\begin{array}{c}\text { Data slice 1 } \\
\text { (before experiment } \\
\text { started) }\end{array}$ & $\begin{array}{c}\text { Data slice 2 } \\
\text { (after experiment } \\
\text { completion) }\end{array}$ \\
\hline High & $26,92^{*}$ & $50,00^{*}$ & 29,16 & 25,00 \\
\hline Medium & $38,46^{*}$ & $38,46^{*}$ & 41,67 & 45,83 \\
\hline Low & $34,62^{*}$ & $11,54^{*}$ & 29,17 & 29,17 \\
\hline
\end{tabular}

$*-p \leq 0,01$ 
cally significant differences were received due to the level of physical health competence development prior to the research and after the completion of forming experiment in the experimental group. In particular, the amount of participants with a high level of competence development increased from $26,92 \%$ to $50,00 \%$, the amount of participants with a low level decreased from $34,62 \%$ (prior to the research launching) to 11,54 $\%$ (after the research completion).

The statistically significant differences among the research results in levels of physical health competence development in the control group were not indicated.

\section{Discussion}

The research results on physical health competence development indicate the efficacy in cognitive behavioral approach implementation in psycho-correctional work. The experimental group participants were able to change their selfattitude and attitude towards their abilities to support their physical health. While discussing the behavioral models of the experimental group participants regarding their physical health they expressed a lot of cognitive beliefs that significantly limited competence development. The participant would call themselves as lazy, not able to finish the task, and no propensity for sports, etc. Negative self-evaluation as being lazy and not inclined to any sports went along with negative emotions, anxiety, (Gross \& Thompson, 2007, Fox \& Calkins, 2003) and anticipation of failure and misfortune (behavioral level).
Implementation of cognitive behavioral techniques assisted in increasing of self-control over negative emotions in the experimental group participants; those emotions were present while they were reaching their goals to improve their physical health. The experimental group participants' goals regarding their physical health improvement often overlapped with the desire to lose weight, look good, and work out some muscles. During training the participants were developing a habit to do morning exercises for 15 minutes, practice jogging and swimming, some of them joined a gym and started attending it no less than twice a week.

While implementing self-efficient behavioral model formation regarding own physical health the following cognitive beliefs were developed, such as: successful, consistent, efficient, persistent, aware of one's health and wellbeing, responsible for one's health, etc. Positive selfattitude impacted positive emotional attitude and desire to move on in the direction of improving one's own physical health.

The important emphasis in the physical health competence formation was directed on individual self-organization. Self-organization is the process that implies rational time consumption, developing self-discipline, and selfmotivational mechanisms for certain activity. Self -organization is a skill to organize oneself for some work, to fulfill one's own and other's agreements, and reach one's own goals. (Ashby, 1947). The problems with the self-organization and self- 
discipline are the result of acquired previous life experiences in organizing different aspects of one's life: education, leisure, hobby, errands, etc.

\section{Conclusion}

The conducted research results indicate the viability of physical health competence formation regardless the age. The desire to maintain one's physical health can stay only at the level of need awareness, and to prevent to do some real steps towards health improvement. At the heart of inactivity towards one's own physical health can be negative experience of failures, lack of selfconfidence, and belief in one's abilities to reach the results, etc. The formation of physical health competence consists of acquiring the knowledge about feasibility to maintain one's own physical health, finding ways of improving it, as well as formation of self-efficacy model in reaching the results. The aggregate of knowledge, skills and positive skills in reaching the results in sport, nutrition and supporting one's own health, selfconfidence and confidence in one's own abilities to control one's own health indicate the high level of physical health competence maturity.

\section{Conflicts of interest}

The authors state that there was no conflict of interests.

\section{References :}

Abramson, L. Y., Seligman, M. E. P. \& Teasdale, J. D. (1978) Learned helplessness in humans: Critique and reformulation. Journal of Abnormal Psychology. № 87. P. 49-74.

Ashby, W. R. (1947) Principles of the Self-Organizing Dynamic System. Journal of General Psychology. № 37. P. 125-128.

Bandura, A. (1992) Social cognitive theory and social referencing. S. Feinman (Ed.). Social referencing and the social construction of reality in infancy. New York.Plenum. P. 175-208.

Bandura, A. (1986) Social foundations of thought and action: a social cognitive theory. Englewood Cliffs, N.J.: Prentice-Hall. ISBN 978-0-13-815614 $\underline{-5}$.

Beck, A. T. (1976) Cognitive therapy and the emotional disorders. American Book. 356 p.

Chepyga, M. \& Chepyga, S. (2006) Health and intelligence stimulation. Kyiv. Znannya. 347 p.

Delamare, Le Deist F. \& Winterton, J. (2005) What Is Competence? Human Resource Development International. Vol. 8. (No. 1). P. 27-46.

Ellis, A. \& MacLaurin, K. (2008) Rational emotional behavioral therapy. Translation from English. Rostov -on-Don: Phoenix, 160 p.

Fox, N. A. \& Calkins, D. (2003) The development of selfcontrol of emotion: Intrinsic and extrinsic influence. Motivation and Emotion. 27 (1). P. 726.

Gross, J. R. \& Thompson, R. (2007) Emotion regulation: Conceptual foundations. Handbook of Emotion Regulation. New York: Guilford Press. 3-24.

Melnyk, Y. (2019) The influence of educational, physical cultural and healthy work on the formation of the 
health culture of master's students Journal of Physical Education and Sport, Vol 19 (Supplement issue 1), Art 33, 219-226.

Murza, V. (1991) Physical exercises and health. Kyiv. Zdorov'ya. $352 \mathrm{p}$.

Rotter, J. B. (1978) Generalized expectancies for problem solving and psychotherapy. Cognitive Therapy and Research. Vol. 2. P. 1-10.

Schippmann, J.S., Ash, R.A., Battista, M. et al. (2000) The practice of competency modeling. Personnel Psychology. 53(3). P. 703-740.

Snyadanko, I. (2016) Polytechnic university student preparation psychology for future professional administrative activity. Monograph. Kyiv-Lviv. 462 p.

Spencer L. M., McClelland, D. C. \& Kelner, S. (1998) Competency Assessment Methods: History and State of the Art. MA: Hay/McBer. - Boston. P. 384-405.

Ziering, D. (2006) Personal helplessness in students: psychological content of structural components. Bulletin SUSU. Series. Education. Healthcare. Physical education. Issue. 8. № 9 (64). P. 17-21.

Zimnyaya, I. (2004) Key competences as result-centered basis for competence approach in education. Moscow. page 40. - Available at: http://rc.edu.ru/rc/ bologna/works/zimnaya_1_sod.pdf3

\section{Сняданко Ірина Ігорівна}

Доктор психологічних наук, дочент, доиент кафедри теоретичної та практичної психології, Національний університет “Львівська політехніка", м. Львів (Украӥна)

\section{Ткалич Маріанна Григорівна}

Доктор психологічних наук, доиент, професор кафедри психології та соціальної роботи Інституту підготовки кадрів Державної служби зайнятості Украӥни, м. Киів (Украӥна)

\section{Войцеховська Оксана Володимирівна}

Кандидат психологічних наук, асистент кафедри теоретичної та практичної психологї, Національний університет “Львівська політехніка”, м. Львів (Україна)

\section{КОГНІТИВНО-ПОВЕДІНКОВИЙ ПІДХІД У РОЗВИТКУ ФІЗИЧНОГО ЗДОРОВ'Я}

\section{Анотація.}

Стаття присвячена дослідженню особливостей застосування когнітивноповедінкового підходу в психологічному консультуванні, що спрямоване на формування компетенції фізичного здоров'я. Розкрито зміст, та основні поняття соціальнокогнітивного підходу, який було засновано А. Бандурою та розвинено представниками його школи. Зокрема розкрито базові поняття, такі як: самоефективність, набута безпорадність, локус контролю, компетенція. За А. Бандурою, під поняттям самоефективність розуміємо впевненість особистості у власних силах та можливостях здійснювати ту чи іншу діяльність. А набуття самоефективності може відбуватись такими шляхами: здатністю вибудовувати поведінку, досвід, вербальні переконання та емоційний стан. Здійснено порівня- 
льний аналіз понять “компетенція" i “компетентність”. Зроблено висновок, що під поняттям компетенція розуміється здатність особистості ефективно виконувати діяльність, як впевненість у собі, своїх можливостях здійснювати цю діяльність, а під поняттям “компетентність" розуміється вже рівень реалізації цих можливостей. Обгрунтовано когнітивно-поведінковий підхід (А. Бек, А. Елліс), модель роботи з психологічною проблемою за допомогою когнітивно-поведінкової схеми. У межах когнітивно-поведінкового підходу, зміст компетенцій являє собою сукупність таких складових: когнітивної, емоційної, поведінкової. Здійснено аналіз понять: фізичне здоров'я, компетенція фізичного здоров'я. Представлено результати експериментального дослідження спрямованого на формування компетенції фізичного здоров'я особистості. Порівняння результатів дослідження рівня розвитку компетенції фізичного здоров'я до початку та після завершення експериментального дослідження свідчать про зростання кількості досліджуваних 3 високим рівнем розвитку самоефективності в діях щодо покращення власного фізичного здоров'я. Зроблено висновок, що впровадження когнітивно-поведінкового підходу є ефективним для формування компетенції фізичного здоров'я.

Ключові слова: самоефективність; компетенція; когнітивно-поведінковий підхід; фізичне здоров'я.

\section{Сняданко Ирина Игоревна}

Доктор психологических наук, дочент, дочент кафедры теоретической и практической психологии, Национальный университет «Львовская политехника», 2. Львов (Украина)

\section{Ткалич Марианна Григорьевна}

Доктор психологических наук, дочент, профессор кафедры психологии и сочиильной работь Института подготовки кадров Государственной службы занятости Украинь,, г. Киев (Украина)

\section{Войцеховская Оксана Владимировна}

Кандидат психологических наук, ассистент кафедры теоретической и практической психологии, Национальный университет «Львовская политехника», г. Львов (Украина)

\section{КОГНИТИВНО-ПОВЕДЕНЧЕСКИЙ ПОД- ХОД В РАЗВИТИИ ФИЗИЧЕСКОГО ЗДО- РОВБЯ}

Аннотация. Статья посвящена исследованию особенностей применения когнитивно-поведенческого подхода в психологическом консультировании, направленное на формирование компетенции физического здоровья. Раскрыто содержание и основные понятия социально-когнитивного подхода, который был основан А. Бандурой и развивался представителями его школы. Раскрыто базовые понятия, такие как: самоэффективность, приобретенная беспомощность, локус контроля, компетенция. За А. Бандурой, под понятием самоэффективность понимаем уверенность личности в собственных силах и возможностях совершать ту или иную деятельность. Приобретение самоэффективности может происходить следующими путями: способность выстраивать поведение, опыт, вер- 
бальные убеждения и эмоциональное состояние. Осуществлен сравнительный анализ понятий “компетенция" и “компетентность”. Сделано вывод, что под понятием компетенция понимается способность личности эффективно выполнять деятельность, как уверенность в себе, своих возможностях осуществлять эту деятельность, а под понятием “компетентность" понимается уже уровень реализации этих возможностей. Обоснованно когнитивно-поведенческий подход (А. Бек, А. Эллис), модель работы с психологической проблемой с помощью когнитивноповеденческой схемы. В рамках когнитивноповеденческого подхода, содержание компетенций представляет собой совокупность следующих составляющих: когнитивной, эмоциональной, поведенческой. Предпринята анализ понятий: физическое здоровье, компетенция физического здоровья. Представлены результаты экспериментального исследования направленного на формирование компетенции физического здоровья личности. Сравнение результатов исследования уровня развития компетенции физического здоровья до начала и после завершения экспериментального исследования свидетельствуют о зростаття количества испытуемых с высоким уровнем развития самоэффективности в действиях по улучшению собственного физического здоровья. Сделан вывод, что внедрение когнитивноповеденческого подхода является эффективным для формирования компетенции физического здоровья.
Ключевые слова: самоэффективность; компетенция; когнитивно-поведенческий подход; физическое здоровье.
Дата отримання статті: 01.06.2019 Дата рекомендації до друку: 20.06.2019 Дата оприлюднення: 25.07.2019 